\title{
Eco Design 2005
}

平成 17 年 12 月 12 日（月） 14 日（水）の 3 日間にわ たってエコデザイン学会連合主催の EcoDesign 2005（4 th International Symposium on Environmentally Conscious Design and Inverse Manufacturing) が学術総合センター （東京）を会場として開催された。本国際シンポジウムは 2 年毎に開催され, 今回は 4 回目にあたる. EcoDesign は, 環境調和型の社会システム, ビジネス, サービス, 製品の 開発と展開を通じて持続可能な社会の構築を目指すもので, 毎回, 幅広い分野の学協会ならびに企業関係者が参加して いる. プラスチック成形加工学会は準会員団体として登録 されており，筆者も組織委員の一人として名を連ねている. 最終参加者は 300 名程度 (未確認) と大きな組織で運営さ れているには少ない印象を受けたが，内容は非常に充害し ていた。

初日は大会組織委員長の古川勇二先生（東京農工大）の 司会でオープニングセレモニーがあり, 先ず, 大会委員長 の山本良一先生（東京大学）の挨拶の後, 「Message from Ministry of the Environment」と題して小池百合子環境大 臣の記念講演があった。種々興味ある話題の中で, 環境革 命のキーワードとして,「Circulation」を挙げられ，「Circulation of global carbon」, 「Circulation of goods and materials」, 「Circulation between the environment and economy」の実現の重要性を強調された。また，「Vision for a Virtuous Circle of Environment and Economy」として薬 用植物名の「HERB」をあげられた。これは Healthy, Ecology and Economy, Rich, Beautiful の頭文字をとったも ので,すなわち,「Healthy, Beautiful and Rich Environmentally-advanced country」の実現を目標とする ものである。この言葉は非常に良い響きで筆者も非常に気 に入っている.さらに昨夏に話題になった「COOL BIZ」 キャンペーンの効果について環境省が調べたデータが示さ れた、それによると，本キャンペーンを知っている人の割 合は $94.9 \%$ ，「COOL BIZ」服装を奨励した会社は $59.6 \%$ ， 本キャンペーンによる6月～8月の電力削減量は 210 milion kWh だったそうである. 今冬は「WARM BIZ」キャン ペーンも行われているが, どの程度の成果が出るか楽しみ である.

\footnotetext{
* Kimura, Teruo

京都工芸繊維大学大学院工芸科学研究科先端ファイブロ科学専攻 京都市左京区松ヶ崎御所海道町 ( $7606-8585$ ) 2006.1.12 受理
}

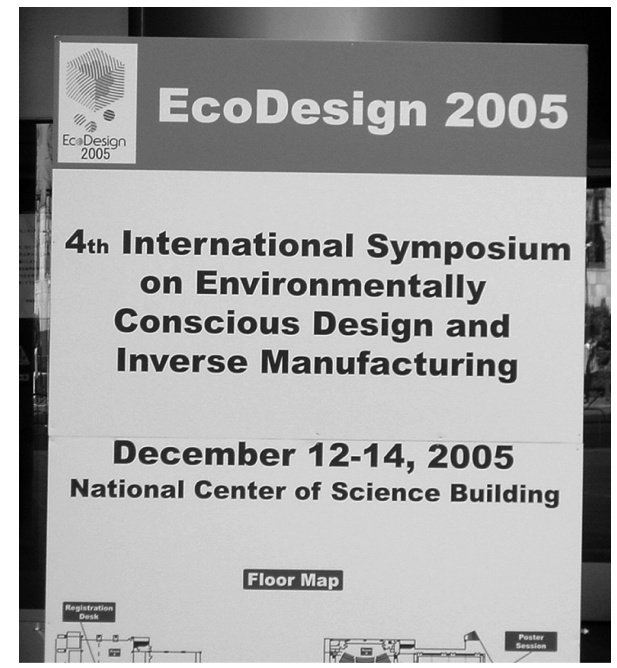

写真 1 EcoDesign 2005 会場案内

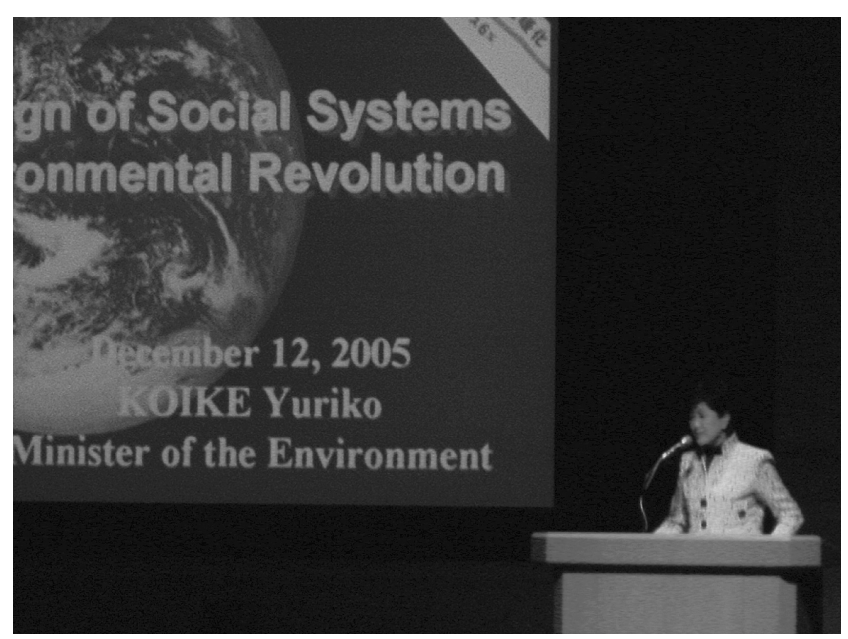

写真 2 小池百合子環境大臣の講演風景

記念講演の後は 5 室に分かれて種々のセッション講演が行 われた。

初日午後には小宮山宏先生 (東大総長) が「Vision 2050 and the Role of Japan toward the Sustainable Society」と 題してプレナリー講演を行われた. その中で印象的であっ たのは, 経済大国日本は世界に先駆けて環境問題に直面し ており, 現在取り組んでいる種々の環境対策研究は他国が 今後直面するであろう環境問題解決のために非常に重要で ある, とのことである.すなわち日本の研究の成果如何に 


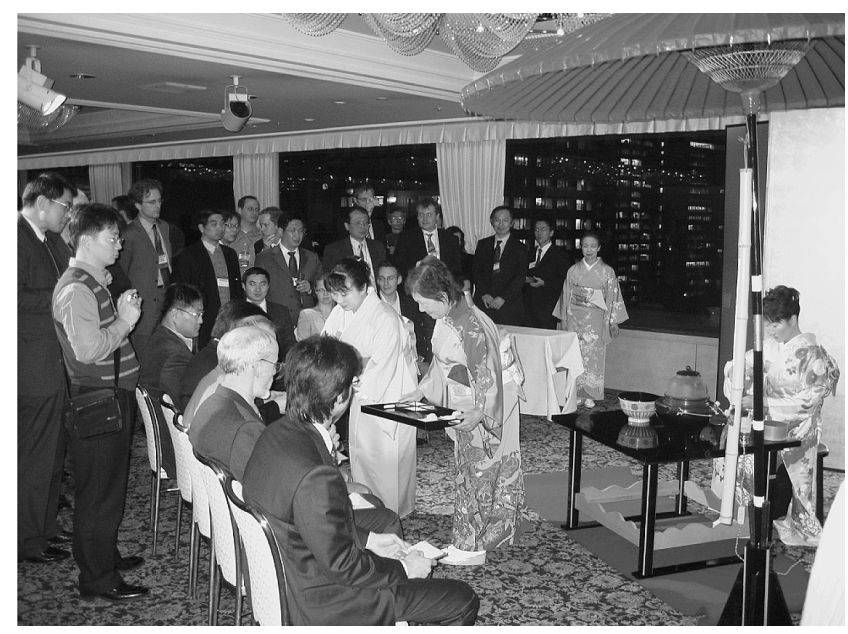

写真 3 懇親会の様子

よって世界の環境問題が解決するか否かがかかっていると の視点で環境保護研究に取り組む必要性を述べられた。

2 日目，3 日目もプレナリー講演と各セッションに分か れて一般講演が行われた.2 日目の夕刻からは会場を KKR ホテル東京に移して夜景のきれいな 10 階の部屋で愁親会 が開催された。国際会議らしく日本茶道学会の協力のもと, 日本的な打茶のサービスもあり，外国からの参加者に非常 に人気があった。

EcoDesign の研究領域を把握するための参考として今回 設けられたセッション名と発表件数（括弧内の数字は海外 からの発表件数）をあげると以下のようである.

1. Sustainable Society and Business (Special Theme) $[4(2)]$

2. Eco-Product and Eco-Material in Asia (Special Theme) [3(3)]

3 . Design for Disassembly [6(4)]

4. Eco-Product [5(1)]

5. Renewable Energy and New Energy Technology [8(1)]

6. Consumer Modeling [4(2)]

7. Biomass-Material $[5(0)]$

8. Tool/Method for DfE $[12(7)]$

9. Recycling System/Technology [6(1) ]

10. EcoDesign Education [4 (2)]

11. Eco-Material $[5(0)]$
12. System Design for Remanufacturing [3(2) ]

13. Waste and Disposal [2(0)]

14. Modular Design [3(0)]

15. Eco-SCM [6 (1)]

16. Service Engineering [6(4)]

17. Remanufacturing [6(3)]

18. Environmental Load Reduction in Asia (Special Theme) [4(1)]

19. Design for Environment in Asia (Special Theme) $[5(2)]$

20. Life Cycle Design [4(4)]

21. LCA for EcoDesign [4(2)]

22. Energy Conservation [5(1)]

23. Recycling in Asia (Special Theme) [7(3)]

24. Life Cycle Scenario and Simulation/Lifetime Estimation $[5(1)]$

25. EcoDesign Tool [5(5)]

26. Life Cycle Cost and Management [3(2)]

27. Eco-Effiency/EcoDesign Impact [10(5) ]

28. Legislation for EcoDesign (Special Theme) [4(2)]

29. End of Life Product [3(2)]

30. Soldering Technology $[8(3)]$

31. JIEP Workshop $[6(0)]$

32. Poster [29 (12)]

解体容易な設計に関するもの，環境負荷の小さい製品設 計に関するもの，再生可能エネルギーに関するもの，水素 エネルギーをはじめとする新エネルギーに関するもの，環 境係数や LCA に関するものなどテーマは多岐にわたって いるが EcoDesign にとってはいずれも大事なテーマであ り, お互いの内容は大いに関連性のあるものである.

内容的にプラスチック成形加工学会と関係が深いと思わ れるセッションは「7」，「9」および「11」であり，「7」の セッションでは，バイオベースポリマーのノートブック $\mathrm{PC}$ などの家電製品への応用や天然繊維であるケナフ繊維 の家電製品への応用についての発表があった。「9」では廃 棄プラスチックの材料リサイクルや瀻維廃材の擬木成形へ の応用などの発表があった。「11」のセッションでは廃家 電プラスチックのリサイクル手法や ABS リサイクルのた めの LCI 解析に関する研究発表があった。

今回のいずれの講演も「ものづくりにとって環境を守る とはどういうことか」を考えさせる良い機会であった。 